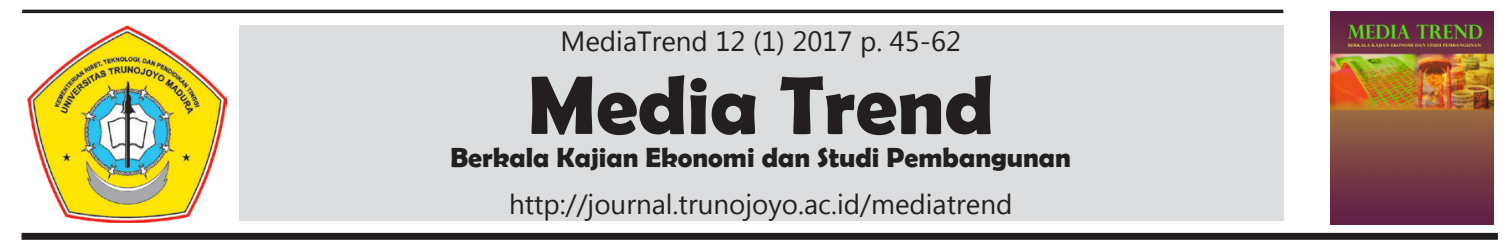

\title{
Implementasi Bangunan Ekonomi Islam Pada Produk Pembiayaan Natural Uncertainty Contract (NUC) di Bank Syariah
}

\section{Trimulato $^{1, *}$}

1,2 Perbankan Syariah Universitas Muhammadiyah Parepare

\begin{tabular}{l} 
Informasi Artikel \\
\hline Sejarah artikel: \\
Diterima Januari 2017 \\
Disetujui Maret 2017 \\
Dipublikasikan Maret \\
2017 \\
\hline Keywords: \\
Islamic Economics Build- \\
ing, \\
Financing Uncertainty \\
Natural Contract (NUC), \\
and Shariah Banking.
\end{tabular}

\begin{abstract}
A B S T R A C T
Shariah banking has had a strong legal law in the presence of shariah banking act number 21 of 2008. The presence of shariah banks in Indonesia are increasingly in demand by the public. Currently the market share of shariah banks has translucent 5\%, and the asset side continues to rise well. Shariah banks attached sharing system, only financing products in Islamic banks still dominated by the sale and purchase murabahah financing. Murabahah financing accounted for 60, 725\%. While profit-sharing agreement with Natural Uncertaintyagreement Contract (NUC) contribute only $39.275 \%$. Shariah banks are part of Islamic economics can not be separated, so that all the products of Islamic banks should be in line with the concept of building an Islamic economy. The aim of research to determine the development of financing mudharabah and Musharakahshariah banking and the implementation of Islamic economics building on financing products natural uncertainty contract (NUC) in shariah banking. The results of this paper show the development of financing products NUC in its development of Islamic banks was minimal. In mudarabah grew 3.246 percent and 23.060 percent Musharakah. Natural financing products Uncertainty Contract (NUC) has fulfilled the concept of building an Islamic economy, only one thing that does not fit that assurance requirements specified on the product of financing in Islamic banks, is considered unfair to customers funds.
\end{abstract}




\section{Pendahuluan}

Seiring dengan perbaikan dan reformasi perbankan nasional pasca krisis ekonomi, perbankan syariah yang merupakan bagian dari perbankan nasional mulai memasuki babak baru implementasi sistem perbankan nasional dengan segala hambatan dan perkembangan yang secara berkala terus diperbaiki sesuai dengan syariat Islam. Perbankan syariah era reformasi dimulai dengan disetujuinya Undang-undang No.10 tahun 1998 tentang perbankan syariah (Antonio; 2001). Kemudian disempurnakan dengan adanya undang-undang Perbankan Syariah nomor 21 tahun 2008.

Ide dasar sistem perbankan Islam sebenarnya dapat dikemukakan dengan sederhana. Operasi institusi keuangan Islam terutama berdasarkan pada prinsip PLS (porfit-and-loss-sharing bagi untung dan rugi). Prinsip bagi hasil ini dalam keuangan Islam sangat dianjurkan dan merupakan solusi yang pantas dan relefan untuk mengatasi masalah alokasi dana yang terbatas, baik yang berupa dana pinjaman atau tabungan dengan maksud supaya pengelolaan dan pembiayaan bisnis secara efektif dapat tercapai. Bank Islam tidak membebankan bunga, melainkan mengajak partisipasi dalam bidang usaha yang didanai. Para deposan juga sama-sama mendapat bagian dari keuntungan bank sesuai dengan rasio yang telah ditetapkan sebelumnya. Dengan demikian ada kemitraan antara bank Islam dan para deposan di satu pihak, dan antara bank para nasabah investasi sebagai pengelola sumber daya para deposan dalam berbagai usaha produktif dipihak lain ( $M$. Algaoud: 2001).

Alasan didirikannya bank syariah diantaranya karena keadilan yang terdapat pada bank syariah. Di kalangan investor Barat terjadi pergeseran paradigma dalam berinvestasi yaitu mereka tidak lagi berinvestasi karena alasan tertarik dengan bunga yang kelihatannya saja menjanjikan keuntungan berlipat ganda seketika. Namun kini mereka lebih kritis penghasilan yang mungkin diperoleh melalui metode institusi pemutaran uang, sehingga sistem bagi hasil yang diterapkan oleh bank syariah lebih logis dan fair bagi mereka. Dengan adanya bank syariah maka semua umat terutama umat Islam terhindar dari riba dalam kegiatan muamalahnya memperoleh kesejahteraan lahir batin dan sesuai dengan perintah agamanya.

Karakteristik sistem perbankan syariah yang beroperasi berdasarkan prinsip bagi hasil memberikan alternatif sistem perbankan yang saling menguntungkan bagi masyarakat dan bank, serta menonjolkan aspek keadilan dalam bertransaksi, investasi yang beretika, mengedepankan nilai-nilai kebersamaan dan persaudaraan dalam berproduksi, dan menghindari kegiatan spekulatif dalam bertransaksi keuangan. Dengan menyediakan beragam produk serta layanan jasa perbankan yang beragam dengan skema keuangan yang lebih bervariatif, perbankan syariah menjadi alternatif sistem perbankan yang kredibel dan dapat dinimati oleh seluruh golongan masyarakat Indonesia tanpa terkecuali (www.bi.go.id).

Jenis pembiayaan yang ada di bank syariah terbagi dua, yaitu pembiayaan dengan akad Natural Certainty Countract (NCC) dan pembiayaan akad Natural Uncertainty contract (NUC). Akad pembiayaan NCC adalah akad yang memberikan kepastian pengembalian dan keuntungan termasuk kepastian waktu, sedangkan akad pembiayaan NUC adalah akad yang tidak memberikan kepastian pengembalian atau keuntungan. Adapun yang masuk dalam akad pembiayaan NCC adalah jual beli murabahah, jual beli salam, jual beli istisnha', ijarah dan Ijarah Muntahiyya Bit Tamlik (IMBT). Adapun akad pembiayaan yang masuk dalam NUC yaitu akad Mudharabah dan akad Musyarakah.

Risiko bank syariah dalam akad pembiayaan NUC potensial tinggi karena sangat mengandalkan kepercayaan yang sangat tinggi sebagai jaminan moral. Dalam literatur fiqih, kedua produk NUC disebut 
sebagi produk dengan akad kepercayaan (uqud al-amanah). Praktek moral hazard mencerminkan pengkhianatan terhadap kepercayaan yang diberikan oleh nasabah kepada bank dan kepercayaan bank pada nasabah. Kepercayaan merupakan faktor yang sangat diandalakn oleh bank syariah sebagai nilai yang berbasis ajaran islam. Kedua akad NUC rentan terhadap praktek moral hazard yang dilakukan nasabah maupun oleh manajemen bank jika tidak ada komitmen moral dalam melaksanakan kontrak. Al-qur'an melarang kita mengkhianati kepercayaan (QS. Al-Maidah ayat 1). Oleh karena itu, manajemen bank syariah perlu menunjukkan komitmen konkrit agar nilai-nilai kepercayaan tetap terjaga selama jangka waktu perjanjian (Alwi: 2013).

Bank syariah lebih dikenal dengan sistem bagi hasil yang mempunyai berbagai produk yang menggunakan akad Mudharabah dan Musyarakah, dianggap lebih adil bagi semua pihak. Namun saat ini sepertinya sudah mulai terjadi pergeseran di bank syariah, Bank syariah lebih senang dan lebih mengunggulkan produk pembiayaan dengan akad Murabahah, yang memberikan hasil yang pasti. Bisa dilihat perbandingan pembiayaan di bank syariah dengan menggunakan akad NCC dan akad NUC.

Dari data dibawah menunjukkan bahwa dari total pembiayaan di bank syariah Desember 2015 sebesar 209.045.000.000.000 masih didominasi penyaluran pembiayaan dengan akad NCC yaitu dengan kontribusi sebesar 63,828 persen. Sedangkan porsi penyaluran pembiayaan dengan akad NUC masih sangat minim dibawah 50 persen yaitu hanya dikisaran 36,132 persen. Padahal kita ketahui bahwa bank syariah itu lebih dikenal sebagai bank bagi hasil bukan bank jual beli. Maka dari itu perlu didorong agar bank syariah bisa mengembalikan jati dirinya sebagai bank bagi hasil. Bank syariah sebagai lembaga keuangan syariah perlu memperlihatkan eksistensinya kepada masyarakat dalam meningkatkan pembiayaan dengan bagi hasil. Diperlukan segmen yang tepat bagi bank syariah untuk berani memberikan pembiayaan dengan akad NUC. Akad NUC betul sangat berisiko tapi juga jangan diabaikan bahwa dengan Bank syariah memberikan NUC maka besar bisa memberikan keuntungan yang lebih besar.

Bank syariah merupakan bagian yang tidak bisa dipisahkan dari konsep ekonomi islam. Jika ingin digambarkan ekonomi islam itu ibarat sebuah pohon, dan bank syariah menjadi bagian selembar

Tabel 1.1

Produk Pembiayaan di Bank Syariah Desember 2015

\begin{tabular}{|c|c|c|c|}
\hline NO & JENIS PEMBIAYAAN & $\begin{array}{c}\text { BESAR } \\
\text { PEMBIAYAAN }\end{array}$ & $\begin{array}{l}\text { FREKUENSI/ } \\
\text { KONTRIBUS। }\end{array}$ \\
\hline \multirow[t]{7}{*}{1} & AKAD PEMBIAYAAN NCC & & \\
\hline & - MURABAHAH & 122.111 & \\
\hline & - SALAM & - & \\
\hline & - ISTISNHA' & 770 & \\
\hline & - IJARAH & 10.631 & \\
\hline & - IMBT & - & \\
\hline & TOTAL & 133.512 & $63,868 \%$ \\
\hline \multirow[t]{4}{*}{2} & AKAD PEMBIAYAAN NUC & & \\
\hline & - MUDHARABAH & 14.820 & \\
\hline & - MUSYARAKAH & 60.713 & \\
\hline & TOTAL & 75.533 & $36,132 \%$ \\
\hline 3 & TOTAL & 209.045 & $100 \%$ \\
\hline
\end{tabular}


daun yang berada dalam tubuh pohon itu. Cakupan ekonomi islam begitu luas, bank syariah menjadi bagian kecil yang dibahas di dalamnya. Ekonomi islam sangat erat kaitannya dengan sektor riil, bahkan dalam ekonomi islam sektor riil jauh lebih utama ketimbang sektor keuangan. Dalam ekonomi islam sektor keuangan hanya sebagai bagian pendukung dalam suatu perekonomian, dan sektor riil adalah penopang utama sistem perekonomian. Maka dari itu bank syariah adalah bagian dari sistem ekonomi islam dan merupakan sektor keuangan yang harus bisa mendukung laju perkembangan sektor riil, menjaga stabilitas ekonomi dan bisa menambah pendapatan suatu negara, dan lebih jauh bisa menciptkan banyak lapangan kerja.

Ekonomi Islam dibangun atas dasar agama islam, karenanya ia merupakan bagian tak terpisahkan integral dari agama islam. Sebagai derivasi dari agama islam, ekonomi islam akan mengikuti agama islam dalam berbagai aspeknya. Islam adalah sistem kehidupan (way of live) yang akan membawa manusia ke hal yang lebih baik sesuai dengan tujuan hidupnya. Ekonomi islam dibangun untuk tujuan suci, dituntun oleh ajaran islam dan dicapai dengan cara-cara yang ditentukan pula oleh ajaran islam. Oleh karena itu, kesemua hal tersebut saling terkait dan terstruktur secara hirarkis, dalam arti bahwa spirit ekonomi islam tercermin dari tujuannya, dan ditopang oleh pilarnya. Tujuan untuk mencapai falah hanya bisa diwujudkan dengan pilar ekonomi islam, yaitu nilai-nilai dasar (islamic values), dan pilar operasional, yang tercermin dalam prinsipprinsip ekonomi islam. Dari sinilah akan tampak suatu bangunan ekonomi islam dalam suatu paradigma, baik paradigma dalam berfikir dan berperilaku maupun bentuk perekonomiannya (Karim: 2003).

Karim (2003) dalam bukunya yang berjudul Bank Islam, Analisi Fiqh dan Keuangan, menjelaskan bahwa bangunan ekonomi Islam didasarkan atas lima nilai universal, yaitu: (1) Tauhid (Keimanan); (2) 'Adl (Keadilan); (3) Nubuwwah (Kenabian); (4) Khalifah (Pemerintahan); (5) Ma'ad (Hasil).

Kelima nilai dasar ini menjadi dasar inspirasi untuk untuk menyusun proposisiproposisi dan teori-teori ekonomi Islam. Dari kelima nilai-nilai universal tersebut, dibangunlah tiga prinsip derivatif yang menjadi ciri-ciri dan cikal bakal sistem ekonomi Islam. Ketiga prinsip derivatif itu adalah: (1) Multitype ownership (Kepemilikan Multijenis); (2) Freedom to act (Kebebasan bertindak dan berusaha); (3) Social justice (Keadilan Sosial).

$\mathrm{Di}$ atas semua nilai dan prinsip tersebut, dibangunlah konsep yang memayungi semuanya, yaitu konsep Akhlak. Akhlak menempati posisi puncak, karena inilah yang menjadi tujuan Islam dan dakwah para Nabi. Akhlaq inilah yang menjadi panduan para pelaku ekonomi dan bisnis dalam melakukan aktivitasnya.

Dalam tulisan ini penulis ingin melihat implementasi dari unsur-unsur dari bangunan ekonomi islam yang kemudian diterapakan dalam produk pembiayaan Natural Uncertainty Contract (NUC) di bank syariah. Produk pembiayaan NUC yang terdiri dari akad mudharabah dan musyarakah yang masih minim digunakan bank syariah perlu mendapat perhatian agar dapat ditingkatkan. Sehingga perlu diketahui implimentasi bangunan ekonomi islam pada produk pembiayaan NUC di bank syariah.

\section{Identifikasi Masalah}

Berdasarkan latar belakang yang telah dipaparkan dan beberapa ulasan yang ada terkait dengan Bangunan Ekonomi Islam dan produk pembiayaan NUC di bank sebagai instrumen yang digunakan dalam produk penyaluran dana dengan sistem bagi hasil, maka dibutuhkan kesusuaian antara bangunan ekonomi islam dengan produk pembiayaan NUC di bank syariah. Hal ini dengan tujuan agar memas- 
tikan bahwa bank syariah bagian dari kecil dari konsep ekonomi islam sejalan dengan konsep bangunan ekonomi islam yang kini banyak diminati masyarakat untuk memilih sekaligus investasi di lembaga keuangan syariah, khususnya di perbankan syariah. Terdapat dua permasalahan utama yang masih dihadapi oleh industri perbankan syariah pada produk penyaluran dana, antara lain: (1) Produk penyaluran dana bank syariah, hampir menyerupai produk bank konvensional, hanya berbeda pada ketentuan sesuai syariah belum terlihat produk yang berbeda secara mencolok; (2) Produk pembiayaan NUC di bank syariah belum maksimal digunakan oleh bank syariah dalam menyalurkan pembiayaan kepada masyarakat. Sehingga dibutuhkan pendekatan antara teori dan praktik, penerapan ekonomi islam secara penuh pada produk-produk di perbankan syariah. Berdasarkan latar belakang diatas maka rumusan masalahnya sebagai berikut: (1) Bagaimana perkembangan pembiayaan Natural Uncertainty Contract (NUC) di bank syariah?; (2) Bagaimana implementasi bangunan ekonomi islam pada produk pembiayaan Natural Uncertainty Contract (NUC) di bank syariah?

\section{Akad Pembiayaan Natural Uncertanty Contract (NUC)}

\section{Mudharabah}

Mudharabah berasal dari kata adhdharbu fil ardhi, yaitu berpergian untuk urusan dagang. Firman Allah dalam surat 73 ayat 20. "Mereka bepergian di muka bumi mencari karunia Allah. "Disebut juga qiradh yang berasal dari kata al-qardhu yang berarti al-qath'u (potongan), karena pemilik memotong sebagian hartanya untuk diperdagangkan dan memperoleh sebagian keuntungan (Sudarsono, 2005).

Secara teknis mudharabah adalah akad kerjasama usaha antara dua pihak dimana pihak pertama (shahibul maal) menyediakan seluruh modal, sedangkan pihak lainnya menjadi pengelola. Keuntungan usaha secara mudharabah dibagi menurut kesepakatan yang dituangkan dalam kontrak, sedangkan apabila rugi ditanggung oleh pemilik modal selama kerugian itu bukan akibat kelalaian si pengelola. Seandainya kerugian itu diakibatkan karena kecurangan atau kelalaian si pengelola, si pengelola harus bertanggungjawab atas kerugian tersebut (Sudarsono, 2005).

\section{Landasan Hukum Mudharabah \\ Al-Qur'an \\ "Dan jika dari orang-orang yang berjalan di muka bumi mencari se- bagian karunia Allah SWT."(QS. Al- Muzzamil :20)}

"Apabila telah ditunaikan shalat maka bertebarlah kamu di muka bumi dan carilah karunia Allah SWT".(QS. AlJumuah : 10)

\section{Al-Hadist}

"Diriwayatkan dari Abbas bahwa Abbas Bin Abdul Muthalib jika memberikan dana kemitra usahanya secara mudharabah ia mensyaratkan agar dananya tidak dibawa mengarungi lautan, menuruni lembah yang berbahaya, atau membeli ternak. Jika menyalahi peraturan tersebut, yang bersangkutan bertanggungjawab atas dana tersebut. Disampaikanlah syarat-syarat tersebut kepada Rasulullah SAW dan Rasulullah pun membolehkannya" (HR.Thabrani).

Dari Shalih bin Suaib bahwa Rasulullah SAW bersabda, "Tiga hal yang didalamnya terdapat keberkatan: jual-beli secara tangguh, muqharadhah (mudharabah), dan mencampuradukkan dengan tepung untuk keperluan rumah bukan untuk di jual" (HR. Ibnu Majah).

Adapun rukun mudharabah yaitu:

(a) Ada pemilik dana; (b) Ada usaha 
yang akan dibagi-hasilkan; (c) Ada nisbah; (d) Ada ijab qabul. Fuqaha sepakat diperbolehkannya syirkah mudharabah. Kebolehan ini juga berdasarkan ijma' yang disandarkan kepada ayat-ayat al-qur'an dan hadist-hadist Nabi saw. Disamping itu, umat manusia sangat membutuhkannya karena tidak semua orang yang mempunyai harta memiliki keahlian dalam mendayagunakan dan mengembangkan hartanya. Begitu pula sebaliknya, tidak semua orang yang mampu mengembangkan harta dan melakukan pekerjaan mempunyai modal. Dengan demikian, eksistensi syirkah mudharabah dapat merealisasikan kemaslahatan kedua belah pihak. (Ath-Tahyar, 2009).

Secara spesifik terdapat bentuk musyarakah yang popular dalam produk perbankan syariah yaitu mudharabah. Mudharabah adalah bentuk kerjasama antara dua atau lebih pihak dimana pemilik modal (shahibul maal) mempercayakan sejumlah modal kepada pengelola (mudharib) dengan suatu perjanjian pembagian keuntungan. Bentuk ini menegaskan kerjasama dengan kontribusi $100 \%$ modal dari shahibul maal dan keahlian dari mudharib.

Transaksi jenis ini tidak mensyaratkan adanya wakil shahibul maal dalam manajemen proyek. Sebagai orang kepercayaan, mudharib harus bertindak hatihati dan bertanggung jawab untuk setiap kerugian yang terjadi akibat kelalaian. Sedangkan sebagai wakil shahibul maal dia diharapkan untuk mengelola modal dengan cara tertentu untuk menciptakan laba optimal.

Pembiayaan mudharabah yang ada pada perbankan syariah merupakan produk unggulan yang seharusnya dikembangkan oleh bank-bank syariah yang ada sekarang ini. Pembiayaan mudharabah sangat relevan dalam upaya untuk meningkatkan produktifitas sektor rill dengan memberikan pembiayaan mudharabah yang dapat meningkatkan potensi dunia usaha terutama UKM dalam meningkatkan jumlah dan kualitas produksinya.

$$
\text { Namun pada kenyatannya }
$$

pembiayaan mudharabah seakan produk yang sangat ditakuti oleh bank-bank syariah yang membuat mereka lebih memilih murabahan sebagai produk yang paling banyak menghasilkan bagi bank syariah. Ini tidak terlepas dari besarnya risiko pada pembiayaan mudharabah, sementera murabahah cenderung memiliki risiko yang jauh lebih kecil daripada pembiayaan mudharabah.

Keadaan dunia usaha yang tidak menentu dan susah diprediksi dan belum lagi kurangnya sumber daya manusia yang berkompeten dalam menjalankan sebuah usaha membuat risiko pemberian kredit modal kerja menjadi sangat besar. Tapi dengan keadaan seperti itu pihak bank syariah seakan menerimanya apa adanya tanpa melakukan terobosan yang berarti untuk meningkatkan kinerjanya dalam meningkatkan pembiayaan mudharabah (http://porakranjau.wordpress.com).

Perbedaan yang esensial dari musyarakah dan mudharabah terletak pada besarnya kontribusi atas manajemen dan keuangan atau salah satu diantara itu. Dalam mudharabah modal hanya berasal dari satu pihak, sedangkan dalam musyarakah modal berasal dari dua pihak atau lebih. Musyarakah dan mudharabah dalam literatur fiqih berbentuk perjanjian kepercayaan (uqud al amanah) yang menuntut tingkat kejujuran yang tinggi dan menjunjung keadilan. Karenanya masingmasing pihak harus menjaga kejujuran untuk kepentingan bersama dan setiap usaha dari masing-masing pihak untuk melakukan kecurangan dan ketidakadilan pembagian pendapatan betul-betul akan merusak ajaran Islam.

Keadaan dunia usaha yang tidak menentu dan susah diprediksi dan belum lagi kurangnya sumber daya manusia yang berkompeten dalam menjalankan sebuah usaha membuat risiko pemberian kredit modal kerja menjadi sangat besar. Tapi 
dengan keadaan seperti itu pihak bank syariah seakan menerimanya apa adanya tanpa melakukan terobosan yang berarti untuk meningkatkan kinerjanya dalam meningkatkan pembiayaan mudharabah (http://porakranjau.wordpress.com).

Perbedaan yang esensial dari musyarakah dan mudharabah terletak pada besarnya kontribusi atas manajemen dan keuangan atau salah satu diantara itu. Dalam mudharabah modal hanya berasal dari satu pihak, sedangkan dalam musyarakah modal berasal dari dua pihak atau lebih. Musyarakah dan mudharabah dalam literatur fiqih berbentuk perjanjian kepercayaan (uqud al amanah) yang menuntut tingkat kejujuran yang tinggi dan menjunjung keadilan. Karenanya masingmasing pihak harus menjaga kejujuran untuk kepentingan bersama dan setiap usaha dari masing-masing pihak untuk melakukan kecurangan dan ketidakadilan pembagian pendapatan betul-betul akan merusak ajaran Islam.

Ketentuan umum pembiayaan mudharabah sebagai berikut: (a) Jumlah modal yang diserahkan kepada nasabah selaku pengelola modal; harus diserahkan tunai, dapat berupa uang atau barang yang dinyatakan nilainya dalam satuan uang. Apabila modal diserahkan secara bertahap, harus jelas tahapannya dan disepakati bersama; (b) Hasil dan pengelolaan modal pembiayaan mudharabah dapat diperhitungkan dengan dua cara: 1) (Perhitungan dari pendapatan proyek (revenue sharing); 2) (Perhitungan dari keuntungan proyek (profit sharing); (c) Hasil usaha dibagi sesuai dengan persetujuan dalam akad, pada setiap bulan atau waktu yang disepakati. Bank selaku pemilik modal menanggung seluruh kerugian kecuali akibat kelalaian dan penyimpangan pihak nasabah, seperti penyelewengan, kecurangan dan penyalahgunaan dana; (d) Bank berhak melakukan pengawasan terhadap pekerjaan namun tidak berhak mencampuri urusan pekerjaan/usaha na- sabah. Jika nasabah cidera janji dengan sengaja misalnya tidak mau membayar kewajiban atau menunda pembayaran kewajiban, dapat dikenakan sanksi administrasi.

Terkait dengan produk pembiayaan Mudharabah di bank syariah telah diatur dalam Fatwa Dewan Syariah Nasional NO: $\quad$ 08/DSN-MUI/IV/2000 Tentang Pembiayaan Mudharabah (QIRADH)'.

Fitur dan Mekanisme Pembiayaan Akad Mudharabah (a) Bank bertindak sebagai pemilik dana (shahibul maal) yang menyediakan dana dengan fungsi sebagai modal kerja, dan nasabah bertindak sebagai pengelola dana (mudharib) dalam kegiatan usahanya; (b) Bank memiliki hak dalam pengawasan dan pembinaan usaha nasabah walaupun tidak ikut serta dalam pengelolaan usaha nasabah, antara lain Bank dapat melakukan review dan meminta bukti-bukti dari laporan hasil usaha nasabah berdasarkan bukti pendukung yang dapat dipertanggungjawabkan; (c) Pembagian hasil usaha dari pengelolaan dana dinyatakan dalam nisbah yang disepakati; (d) Nisbah bagi hasil yang disepakati tidak dapat diubah sepanjang jangka waktu investasi, kecuali atas dasar kesepakatan para pihak; (e) Jangka waktu Pembiayaan atas dasar Akad Mudharabah, pengembalian dana, dan pembagian hasil usaha ditentukan berdasarkan kesepakatan Bank dan nasabah; (f) Pembiayaan atas dasar Akad Mudharabah diberikan dalam bentuk uang dan/atau barang, serta bukan dalam bentuk piutang atau tagihan; (g) Dalam hal Pembiayaan atas dasar Akad Mudharabah diberikan dalam bentuk uang harus dinyatakan secara jelas jumlahnya; (h) Dalam hal Pembiayaan atas dasar Akad Mudharabah diberikan dalam bentuk barang, maka barang tersebut harus dinilai atas dasar harga pasar (net realizable value) dan dinyatakan secara jelas jumlahnya; (i) Pengembalian Pembiayaan atas dasar Mudharabah dilakukan dalam dua cara, yaitu secara angsuran atau- 
pun sekaligus pada akhir periode Akad, sesuai dengan jangka waktu Pembiayaan atas dasar Akad Mudharabah; (j) Pembagian hasil usaha dilakukan atas dasar laporan hasil usaha pengelola dana (mudharib) dengan disertai bukti pendukung yang dapat dipertanggungjawabkan; (k) Kerugian usaha nasabah pengelola dana (mudharib) yang dapat ditanggung oleh Bank selaku pemilik dana (shahibul maal) adalah maksimal sebesar jumlah pembiayaan yang diberikan (ra'sul maal).

\section{Akad Musyarakah}

Musyarakah adalah produk finansial syariah yang berbasis kemitraan sebagaimana halnya mudharabah. Namun kedua produk finansial tersebut memiliki ciri-ciri dan syarat-syarat yang berbeda. Istilah lain yang digunakan untuk musyarakah adalah sharikah atau syirkah. Musyarakah diterjemahkan dalam bahasa inggris dengan partnership (kemitraan). Istilah tersebut tidak spesifik karena mudharabah juga suatu partnership (kemitraan). Lembaga-lembaga keuangan islam menerjemahkannya dengan istilah "participation financing" agar dapat lebih menggarisbawahi salah satu aspek dari musyarakah yang akan dijelaskan selanjutnya. Musyarakah dapat diterjemahkan kedalam bahasa indonesia dengan "kemitraan para pemodal" atau "perkongsian para pemodal” (Remy, 2014).

Pada metode pembiayaan musyarakah, bank dan calon nasabah bersepakat untuk bergabung dalam suatu kemitraan (partnership) dalam jangka waktu tertentu. Kedua belah pihak menempatkan modal untuk membiayai suatu proyek dan bersepakat untuk membagi keuntungan bersih secara proporsional yang ditentukan diawal. Tidak ada suatu formula yang pasti bagi pembagian keuntungan tersebut. Hal itu ditentukan dengan secara kasus per kasus. Kesepakatan tersebut dapat berlangsung untuk jangka waktu yang pendek saja, misalnya untuk beberapa minggu atau beberapa bulan, namun dapat pula berlangsung untuk beberapa tahun lamanya (Remy, 2014).

Ibn Rusyd mengartikan syirkah atau musyarakah itu sebagai akad kerjasama antara dua pihak atau lebih untuk suatu usaha tertentu dimana setiap pihak memberikan kontribusi dana dengan kesepakatan bahwa keuntungan dan risiko akan ditanggung bersama sesuai dengan kesepakatan. Syirkah ini disepakati oleh kalangan fuqaha akan kebolehannya selagi memenuhi rukunnya, yaitu ijab dan qabul, untuk memperjelaskan bentuk transaksinya (Iska, 2012).

Akad musyarakah digunakan oleh bank untuk memfasilitasi pemenuhan sebagian kebutuhan permodalan nasabah guna menjalankan usaha atau proyek yang disepakati. Nasabah bertindak sebagai pengelola usaha dan bank sebagai mitra dapat sebagai pengelola usaha sesuai dengan kesepakatan. Pembagian keuntungan dari pemakaian dana dinyatakan dalam bentuk nisbah. Nisbah bagi hasil yang disepakati tidak dapat diubah sepanjang jangka waktu investasi kecuali atas dasar kesepakatan para pihak. Nisbah bagi hasil dapat ditetapkan secara berjenjang (tiering) yang besarnya berbeda-beda berdasarkan kesepakatan. Pembagian keuntungan dapat dilakukan dengan cara bagi untung atau rugi (profit and loss sharing) atau bagi pendapatan (revenue sharing). Pembagian keuntungan berdasarkan hasil usaha sesuai dengan laporan keuangan nasabah. Dalam hal kerugian bank dan nasabah memegang kerugian secara proporsional sesuai modal masing-masing. Jika terjadi kerugian karena kecurangan, kelalaian atau menyalahi perjanjian maka kerugian tersebut ditanggung oleh pihak yang melakukan kecurangan tersebut (Muhamad, 2012).

\section{Konsep Bangunan Ekonomi Islam}

Ekonomi islam muncul dari sebagai refleksi atas kekaaffahan keislaman 
seorang muslim. Ekonomi islam merupakan bentuk evolusi atas teori ekonomi noeklasik. Ekonomi islam muncul di saat perekonomian modern lambat dalam menghadirkan solusi atas problematika ekonomi kontemporer, kalau tidak boleh dikakatakan tidak mampu untuk menghadirkan alternatif solusi (Al-Mishri, 2006). IImu ekonomi islam adalah sebuah sistem ekonomi yang menjelaskan segala fenomena tentang perilaku pilihan dan pengambilan keputusan dalam setiap unit ekonomi dengan memasukkan tata aturan syariah sebagai variabel indevenden (ikut mempengaruhi segala pengambilan keputusan ekonomi) (Al-Mishri, 2006).

Dari sudut pandang ilmu fiqih, kegiatan ekonomi bukanlah termasuk ibadah mahdah, melainkan bab muamalah. Oleh karena itu, berlaku kaidah fiqih yang menyatakan bahwa Al-ashl fi al-mu'amalah al-ibahah, illa idza ma dalla al-dalil ala khilafihi, yakni suatu perkara muamalah pada dasarnya diperkenankan halal untuk dijalankan, kecuali jika ada bukti larangan dari sumber agama (al-qur'an dan sunnah). Oleh karena itu tidak dibenarkan melarang sesuatu yang dibolehkan Allah, sebagaimana tidak boleh pula membolehkan sesuatu yang jelas hal itu dilarang.

Menurut muhammad Baqir as-sadr bahwa ekonomi islam adalah sebuah ajaran atau doctrine dan bukannya ilmu murni (science), karena apa yang terkandung dalam ekonomi islam bertujuan memberikan solusi hidup yang paling baik, sedangkan ilmu ekonomi hanya akan mengantarkan kita kepada pemahaman bagaimana kegiatan ekonomi berjalan. Ekonomi islam tidak hanya sekedar ilmu, tapi lebih dari pada itu, yaitu ekonomi islam adalah sebuah system (Al-Mishri, 2006)

Dengan demikian yang dimaksud dengan sistem ekonomi islam tidak lain adalah segenap pandangan atau keyakinan yang bersumber dari islam, yaitu alqur'an dan as-sunnah terhadap alokasi berbagai sumber daya ekonomi yang ada di bumi ini. Segenap pandangan tersebut kemudian disusun sehingga menghasilkan sistem ekonomi islam yang utuh dan siap diaplikasikan dalam kehidupan yang nyata (Condro, 2012).

Ekonomi islam mengalami kebangkitan setelah tenggelam dalam sejarah beberapa abad yang silam. Ekonomi islam kini kembali sebagai solusi dari sistem perekonomiaan yang ada saat ini yang sudah dianggap gagal dalam mengatur kehidupan manusia. Ekonomi islam tetap akan berkosentrasi pada aspek alokasi dan distribusi sumber-sumber daya, dengan tujuan utamanya merealisasikan maqasid. Suatu perekonomian dapat dikatakan adil jika barang dan jasa yang diproduksi dapat didistribusikan dalam suatu cara dimana kebutuhan individu (tanpa memandang apapun), dapat dipenuhi secara memadai dan juga terdapat distribusi kekayaan dan pendapatan yang adil tanpa berdampak buruk pada motivasi kerja, menabung, investasi, dan melakukan usaha (Chapra, 2001).

Paradigma ekonomi islam mencerminkan suatu pandangan dan perilaku pencapaian falah. Paradigma ekonomi islam bisa dilihat dari dua sudut pandang, yaitu paradigma berfikir dan berperilaku (behaviour paradigm) serta paradigma umum (grand pattern). Sistem ekonomi islam akan mencakup kesatuan mekanisme dan lembaga yang dipergunakan untuk mengoperasionalkan pemikiran dan teori-teori ekonomi islam dalam kegiatan produksi, distribusi, dan konsumsi. (P3EI UII, 2008).

Karim (2003) dalam bukunya yang berjudul Ekonomi Mikro Islam, menjelaskan bahwa bangunan ekonomi Islam didasarkan atas lima nilai universal, yaitu: (a) Tauhid (Keimanan): Tauhid merupakan fondasi ajaran Islam. Dengan tauhid, manusia secara menyeluruh akan menyerahkan segala aktifitasnya kepada Allah. Oleh karena itu, segala aktifitas akan selalu dibingkai dalam kerangka hubungan 
kepada Allah; (b) 'Adl (Keadilan): Dalam Islam, adil didefinisikan sebagai tindakan tidak menzhalimi dan dizhalimi. Implikasi ekonomi dari nilai ini adalah bahwa pelaku ekonomi tidak dibolehkan untuk mengejarkan keuntungan pribadi, namun merugikan orang lain atau merusak alam; (c) Nubuwwah (Kenabian): Salah satu fungsi dari Rasul adalah untuk menjadi model terbaik bagi manusia yang harus diteladani untuk mendapatkan keselamatan dunia dan akhirat. Nabi Muhammad adalah model terbaik yang Allah utus untuk dijadikan tauladan oleh seluruh manusia. Keteladanan Nabi Muhammad mencakup seluruh aspek kehidupan, termasuk teladan dalam bertransaksi ekonomi dan bisnis. Empat sifat utama Nabi yang dapat dijadikan teladan adalah siddiq, amanah, fathanah, dan tabligh; (d) Khalifah (Pemerintahan): Dalam Al Quran, Allah menyebutkan bahwa manusia diciptakan adalah untuk menjadi khalifah dibumi. Peran khalifah adalah untuk menjadi pemimpin dan pemakmur bumi; (e) Ma'ad (Hasil): Implikasi nilai ini adalah dalam perekonomian dan bisnis bahwa motivasi para pelaku bisnis adalah untuk mendapatkan hasil di dunia (laba/ profit) dan hasil di akhirat (pahala).

Kelima nilai dasar ini menjadi dasar inspirasi untuk untuk menyusun proposisi-proposisi dan teori-teori ekonomi
Islam. Dari kelima nilai-nilai universal tersebut, dibangunlah tiga prinsip derivatif yang menjadi ciri-ciri dan cikal bakal sistem ekonomi Islam. Ketiga prinsip derivatif itu adalah: (a) Multitype ownership (Kepemilikan Multijenis): Nilai tauhid dan keadilan melahirkan konsep Multitype ownership atau kepemilikan multijenis. Dalam sistem ekonomi kapitalis, prinsip umum kepemilikan yang berlaku adalah kepemilikan swasta atau pemodal, sedang dalam sistem ekonomi sosialis yang berlaku adalah kepemilikan negara. Dalam sistem ekonomi Islam, mengakui bermacam bentuk kepemilikan, baik oleh swasta, negara, atau campuran; (b) Freedom to act (Kebebasan bertindak dan berusaha): Keempat sifat utama Nabi jika digabungkan dengan nilai keadilan dan nilai khalifah akan melahirkan prinsip freedom to act atau kebebasan bertindak dan berusaha bagi setiap muslim. Islam memberikan kebebasan kepada setiap muslim dalam hal muamalah, namun kebebasan tersebut memiliki batasan-batasan yang tidak boleh dilanggar; (c) Social justice (KeadiIan Sosial): Prinsip Social Justice lahir dari gabungan nilai khalifah dan nilai ma'ad. Semua sistem ekonomi yang ada pasti memiliki tujuan yang sama yaitu untuk menciptakan sistem perekonomian yang adil. Keadilan dalam pendistribusian kekayaan

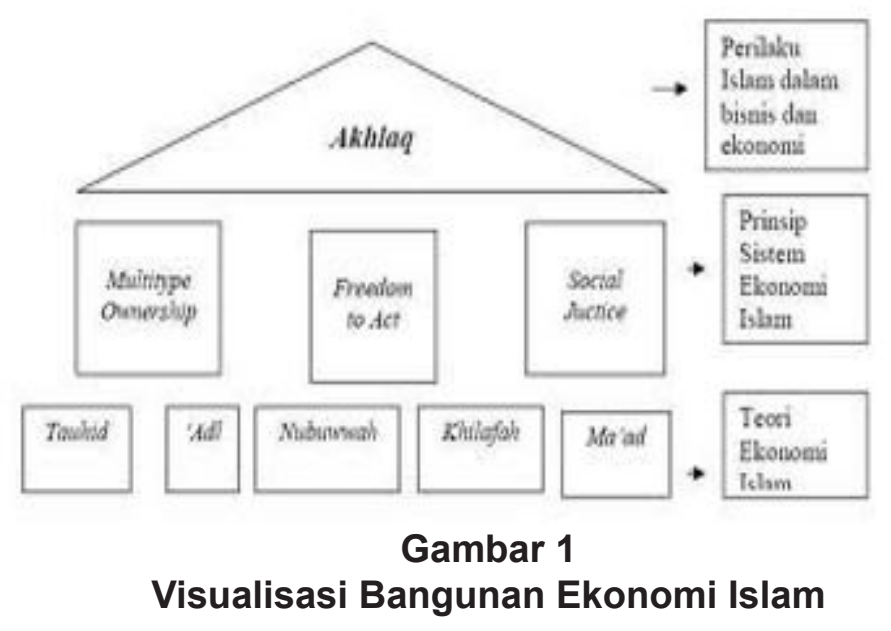


adalah bagian dari prinsip ekonomi Islam. Islam melarang umatnya untuk menumpuk kekayaan pada satu kelompok, namun kekayaan haruslah didistrbusikan secara merata. Kewajiban Zakat, Infak, dan shadaqah bagi golongan yang mampu adalah bentuk pendistribusian kekayaan dalam ekonomi Islam.

Di atas semua nilai dan prinsip tersebut, dibangunlah konsep yang memayungi semuanya, yaitu konsep Akhlak. Akhlak menempati posisi puncak, karena inilah yang menjadi tujuan Islam dan dakwah para Nabi. Akhlak inilah yang menjadi panduan para pelaku ekonomi dan bisnis dalam melakukan aktivitasnya.

Prinsip-prinsip ekonomi Islam yang telah dijelaskan diatas membentuk keseluruhan kerangka ekonomi Islam, jika digambarkan sebuah bangunan ekonomi Islam dapat divisualisasikan padagambar 1.

Prinsip merupakan suatu mekanisme atau elemen pokok yang menjadi struktur atau kelengkapan suatu kegiatan atau keadaan. Dalam contoh shalat, prinsip dicerminkan dari rukun dan syarat sahnya shalat yang membuat suatu kegiatan bisa disebut sebagai shalat (Karim, 2003). Begitupun dalam ekonomi islam juga memiliki berbagai prinsip-prinsip yang membangunnya. Bangunan ekonomi islam didasarkan atas lima universal, yakni: Tauhid (Keimanan), Adl (Keadilan), Nubuwwah (Kenabian), Khilafah (Pemerintahan), dan Ma'ad (Hasil). Kelima nilai ini menjadi dasar inspirasi untuk menyusun proporsi-proporsi dan teori-teori ekonomi islam. Teori yang kuat dan baik tanpa diterapkan menjadi sistem, akan menjadikan ekonomi islam hanya sebagai kajian ilmu saja tanpa memberi dampak pada kehidupan ekonomi. Oleh karena itu, dari kelima nilai-nilai universal ini dibangunlah ciri-ciri dan cikal bakal sistem ekonomi islam. Ketiga prinsip derivatif itu adalah multitype ownership, freedom to act dan sosial justice. Diatas prinsip-prinsip ekonomi islam tersebut dibangunlah konsep yang memayungi kesemuanya, yakni konsep akhlak. Akhlak menempati posisi puncak, karena inilah yang menjadi tujuan islam dan dakwah para nabi, yakni untuk menyempurnakan akhlak manusia. Akhlak inilah yang menjadi panduan para pelaku ekonomi dan bisnis dalam melakukan aktifitasnya (Karim, 2003).

\section{Metode Penelitian}

Jenis penelitian yang digunakan dalam tulisan ini adalah dengan menggunakan studi pustaka yang diperoleh dari beberapa sumber. Penelitian ini bersifat deskriptif kualitatif yang artinya menggambarkan suatu subyek penelitian. Dalam hal ini adalah bentuk produk pembiayaan NUC di bank syariah. Kemudian tentang konsep bangunan ekonomi islam. Sifat penelitian ini adalah deskriptif. Maksudnya untuk mendeskripsikan dan menginterpretasikan hasil temuan/pengamatan mengenai konsep bangunan ekonomi islam dalam produk pembiayaan NUC pada perbankan syariah.

Jenis data yang digunakan dalam tulisan ini adalah data kualitatif yang bersumber dari data primer dan data sekunder. Data primer berupa sumber data yang langsung memberikan data kepada peneliti atau data yang diperoleh langsung dari lapangan (objek penelitian), sedangkan data sekunder adalah sumber data yang tidak langsung memberikan data kepada pengumpul data (peneliti) atau data yang diambil peneliti sebagai pendukung atas penelitian secara ilmiah yaitu dengan melakukan studi pustaka (penelusuran melalui buku, artikel, jurnal, majalah, internet dan sumber lainnya). (Farizal;2010).

Data-data yang digunakan penulis antara lain: (1) Teori-teori yang peneliti ambil dari berbagai literatur; (2) Pengambilan data-data dari hasil yang telah tersaji dari suatu lembaga.

Batasan dalam tulisan ini difokuskan pada produk penyaluran dana yaitu yang ada di bank syariah khususnya produk pembiayaan NUC yaitu hanya 
pada produk pembiayaan mudharabah dan musyarakah di bank syariah. Kemudian bentuk penerapannya pada konsep bangunan ekonomi islam. Batasan dalam tulisan ini juga pada kondisi faktual dari produk pembiayaan NUC di bank syariah, yang terjadi pada bank syariah saat ini yang market sharenya baru menembus angka $5 \%$ apabila dibandingkan perbankan secara nasional.

\section{Teknik Pengumpulan Data}

Teknik pengumpulan data yang diperlukan dalam tulisan ini adalah dengan menggunakan beberapa metode yaitu: (1) Studi Kepustakaan, metode ini digunakan untuk menggali dasar-dasar teori yang terkait produk penyaluran dana dengan akad pembiayaan NUC yaitu mudharabah dan musyarakah pada produk pembiayaan di bank syariah dan teori tentang konsep bangunan ekonomi islam; (2) Pengamatan, setiap data yang didapatkan dari berbagai sumber diamati dan dianalisa terkait dengan kondisi produk pembiayaan NUC di bank syariah dan teori konsep bangunan ekonomi islam.

\section{Analisis Data}

Metode analisis data yang digunakan adalah dengan menggunakan pendekatan kualitatif deskriptif yaitu dengan cara memaparkan metode teori produk pembiayaan NUC dibanksyariah, sertakonsep bangunan ekonomi islam. Kemudian bagaimana penerapan konsep bangunan ekonomi islam pada produk pembiayaan NUC di bank syari'ah sebagai produk yang bisa dimanfaatkan dana masyarakat.

Penelitian kualitatif adalah prosedur penelitian yang menghasilkan data deskriptif berupa kata-kata tertulis atau lisan dari orang-orang dan keadaan yang diamati. Penelitian kualitatif adalah metode penelitian yang digunakan untuk meneliti pada kondisi objek yang alamiah, (sebagai lawannya adalah eksprimen) dimana peneliti adalah sebagai instrument kunci, teknik pengumpulan data dilakukan secara trianggulasi (gabungan), analisa data bersifat induktif dan hasil dari penelitian kualitatif lebih bersifat makna daripada generalisasi (Farizal;2010).

\section{Hasil dan Pembahasan \\ Perkembangan Produk Pembiayaan dengan Akad Natural Uncertanty Coun- tract (NUC) di Bank Syariah}

Dari data diatas menunjukkan bahwa jenis pembiayaan musyarakah paling mengalami pertumbuhan pada tahun 2015 sebesar 23,060 persen. Sedangkan pertumbuhan akad pembiayaan dengan akad mudharabah hanya tumbuh sebesar 3,246 persen lebih keciljika dibandingkan dengan akad pembiayaan murabahah yang tumbuh sebesar 4,038 persen. Hal ini menunjukkan masih ada akad pembiayaan NCC yang lebih dominan dibanding akad pembiayaan NUC. Namun secara nominal jika kedua akad pembiayaan NUC digabungkan masih lebih kecil jika dibandingkan dengan

Tabel 3.1

Perkembangan akad pembiayaan di Bank Syariah

\begin{tabular}{ccccc}
\hline NO & JENIS & DESEMBER & DESEMBER & PERTUMBUHAN \\
& PEMBIAYAAN & $\mathbf{2 0 1 4}$ & $\mathbf{2 0 1 5}$ & \\
\hline 1 & Mudharabah & 14.354 & 14.820 & $3,246 \%$ \\
2 & Musyarakah & 49.336 & 60.713 & $23,060 \%$ \\
3 & Murabahah & 117.371 & 122.111 & $4,038 \%$ \\
4 & ljarah & 11.620 & 10.631 & $-8,512 \%$ \\
5 & Qard & 5.965 & 3.961 & $-33,596 \%$ \\
6 & TOTAL & 198.646 & 212.236 & $6,841 \%$ \\
\hline
\end{tabular}

Sumber : OJK. Statistik Perbankan Syariah (Data diolah) *Dalam Milyar Rupiah 
akad NCC. Perlu upaya agar pembiayaan NUC di bank syariah harus ditingkatkan.

\section{Implementasi Bangunan Ekonomi Islam pada Produk Pembiayaan Natural Un- certainty Contract (NUC) di Bank Sya- riah \\ Tauhid}

Tauhid merupakan fondasi ajaran

Islam. Dengan tauhid, manusia secara menyeluruh akan menyerahkan segala aktifitasnya kepada Allah. Oleh karena itu, segala aktifitas akan selalu dibingkai dalam kerangka hubungan kepada Allah.

Pada produk pembiayaan mudharabah dan musyarakah di bank syariah tidak lepas dari unsur tauhid, kepasrahan dan ketaatan kepada Allah. Kepasrahan kepada Allah seutuhnya dan mengakui keesaan Allah SWT. Hal ini nampak pada produk pembiayaan mudharabah dan musyarakah di bank syariah, nasabah yang memilih produk akan diberi bagi hasil bukan bunga yang dijanjikan diawal. Karena bunga bertentangan dengan islam dan masuk dalam kategori riba. Bagi hasil yang diperoleh nasabah asli dari hasil pendapatan yang diperoleh pihak bank syariah. Sehingga besaran nominal yang diperoleh nasabah bersifat tidak tetap dan tidak pasti, hanya yang disepakati dari awal besaran porsi bagi hasil atau biasa disebut dengan nisbah.

Selanjutnya, wujud penerapan tauhid pada produk pembiayaan mudharabah dan musyarakah di bank syariah yaitu nampak bahwa setiap nasabah yang menggunakan pembiayaan mudharabah dan musyarakah hanya akan disalurkan pada hal-hal yang sesuai dengan aturan islam tidak bertentangan dengan perintah Allah SWT. Hanya pada usaha yang halal saja.

\section{'AdI (Keadilan).}

Dalam Islam, adil didefinisikan sebagai tindakan tidak menzhalimi dan dizhalimi. Implikasi ekonomi dari nilai ini adalah bahwa pelaku ekonomi tidak dibolehkan untuk mengejarkan keuntungan pribadi, namun merugikan orang lain atau merusak alam.

Penerapan Adl' (Keadilan) pada produk pembiayaan mudharabah dan musyarakah di bank syariah, terlihat bahwa setiap nasabah yang memilih pembiayaan mudharabah dan musyarakah akan diberi bagi hasil dari keuntungan yang diperoleh. Telah ditetapkan diawal besaran porsi nisbah antara pihak nasabah dengan pihak bank syariah. Misalnya 60:40 (pihak bank akan memperoleh porsi $60 \%$ dan nasabah akan memperoleh 40\%). Hal ini Nampak keadilan bahwa semua pihak memperoleh keuntungan yang telah disepakati sebagaimana perannya nasabah pembiayaan mudharabah sebagai mudharib (pengelolah) dan bank syariah sebagai pengelolah (shahibul maal) dan pada pembiayaan musyarakah sama-sama menyertakan modal, jika sama-sama memperoleh keutungan tidak hanya menguntungkan satu pihak.

Selanjutnya, unsur keadilan tidak nampak pada pembiayaan mudharabah dan musyarakah di bank syariah ketika bank syariah mensyarakatkan jaminan kepada nasabah. Nasabah akan diberatkan dengan adanya jaminan khususnya bagi nasabah yang tidak mampu dan tidak memiliki jaminan. Prinsip awal dari mudharabah pihak nasabah (mudharib) dan tidak perlu menyerahkan jaminan, hanya dengan modal skilll keahlian dalam mengelolah dana. Pada produk pembiayaan musyarakah nasabah juga menyertakan modalnya. Sehingga uraian tentang jaminan perlu ada agar nasabah tidak menyalahi aturan/perjanjian dianggap tidak adil bagi nasabah selaku mudharib, sejalan dengan musyarakah yang telah menyertakan modal. Karena tidak semua pihak nasabah memiliki jaminan.

\section{Nubuwwah (Kenabian).} Keteladanan Nabi Muhammad 
mencakup seluruh aspek kehidupan, termasuk teladan dalam bertransaksi ekonomi dan bisnis. Empat sifat utama Nabi yang dapat dijadikan teladan adalah siddiq, amanah, fathanah, dan tabligh.

Penerapan sifat siddiq pada produk pembiayaan mudharabah dan musyarakah di bank syariah, yaitu jika bank syariah sebagai shahibul maal dan nasabah sebagai mudharib benar-benar dapat dipercaya bahwa dana tersebut dikelolah secara baik dan benar tidak melakukan kecurangan. Dana terhindar dari hal-hal yang dilarang hanya dikelolah pada sesuatu yang tidak melanggar aturan syariah. Kemudian siddiq pada aspek hasil dari pengelolaan dana, hasil yang diberikan antara bank dan nasabah sesuai dengan porsi yang sebenarnya/ yang telah disepakati diawal. Bank mempercayakan sepenuhnya dan kepada nasabah mudharib akan pengelolaan dana yang disalurkannya, agar dikelola secara baik dan benar serta menguntungkan.

Penerapan sifat amanah, pada produk pembiayaan mudharabah dan musyarakah di bank syariah yaitu dana bank dapat terjamin dikelolah secara baik. Ketika dana nasabah mudharib sudah jatuh tempo maka nasabah mudharib harus bisa mengembalikannya. Nasabah mudharib tidak dibenarkan jika menunda pembayaran bagi hasil jika telah mendapatkan keuntungan. Waktu sesuai dengan kesepatakan keduanya.

Penerapan sifat fathanah pada produk pembiayaan mudharabah dan musyarakah di bank syariah, yaitu dana yang disalurkan pembiayaan yang selain terjamin kehalalannya tapi juga bisa memberikan keuntungan sehingga bagi hasil yang kompetitif. Pihak nasabah mudharib akan secara bijak dan cerdas menggunakan dana yang dikelolahnya. Mudharib harus pandai mengelolah dana tersebut menetukan usaha yang tepat dan menguntungkan.

Penerapan tabliq pada produk pembiayaan mudharabah dan musyarakah di bank syariah yaitu ketika dari hasil pengelolaan dana. Pada awal akad pembiayaan dilakukan antara bank syariah selaku shohibul maal dan nasabah sebagai mudharib menyampaikan besar nisbah serta jangka waktu pembiayaan mudharabah dan musyarakah. Pihak nasabah mudharib akan menyampaikan/ melaporkan setiap keuntungan yang diperolehnya kepada bank syariah. Pihak nasabah mudharib harus transparan dalam menyampaikan keuntungan yang sebenarnya diperolehnya. Kemudian setiap bulan bank syariah akan mendapatkan angsuran yang terdiri dari pembayaran pokok dan porsi keuntungannya. Pada laporan itu akan nampak besaran keuntungan yang diperoleh pihak antara nasabah dan bank syariah.

\section{Khalifah (Pemerintahan).}

Dalam Al Quran, Allah menyebutkan bahwa manusia diciptakan adalah untuk menjadi khalifah dibumi. Peran khalifah adalah untuk menjadi pemimpin dan pemakmur bumi.

Penerapan khalifah pada produk pembiayaan mudharabah dan musyarakah di bank syariah, yaitu nampak bahwa keberadaan pembiayaan mudharabah dan musyarakah di bank syariah adalah sesuatu yang sah/ legal karena telah tertuang dalam undang-undang nomor 21 tahun 2008 dan sejalan dengan Fatwa DSN MUI nomor 7 tahun 2000 tentang pembiayaan mudharabah di bank syariah. Jadi produk pembiayaan mudharabah dan musyarakah adalah sesuatu yang telah dijamin keberadaannya oleh pemerintah.

\section{Ma'ad (Hasil).}

Implikasi nilai ini adalah dalam perekonomian dan bisnis bahwa motivasi para pelaku bisnis adalah untuk mendapatkan hasil di dunia (laba/profit) dan hasil di akhirat (pahala).

Penerapan ma'ad pada produk 
pembiayaan mudharabah dan musyarakah di bank syariah yaitu nampak bahwa setiap dana pembiayaan mudharabah dan musyarakah akan disalurkan pada kegiatan yang memberikan hasil/ keuntungan. Jelas bahwa orientasinya hasil dunia dan akhirat. Hasil laba bank syariah akan menyalurkan dana yang bisa memberikan keuntungan bagi nasabah dan bank. Hasil akhirat bahwa dana nasabah dijamin akan disalurkan pada usaha-usaha yang halal saja yang tidak melanggar aturan agama. Berbeda dengan bank konvensional yang mengabaikan aspek halal dan haram hanya fokus pada memberikan keuntungan, artinya mengabaikan pada hasil akhirat. Lebih lanjut dana pembiayaan mudharabah akan digunakan membiayai usaha untuk pengembangan usaha, yang artinya pembiayaan mudharabah secara tidak langsung membantu nasabah lain dalam pengembangan usaha pada sektor riil. Meningkatkan perkembangan perekonomian masyarakat.

\section{Multitype Ownership (Kepemilikan Multijenis)}

Nilai tauhid dan keadilan melahirkan konsep Multitype ownership atau kepemilikan multijenis. Dalam sistem ekonomi kapitalis, prinsip umum kepemilikan yang berlaku adalah kepemilikan swasta atau pemodal, sedang dalam sistem ekonomi sosialis yang berlaku adalah kepemilikan negara. Dalam sistem ekonomi Islam, mengakui bermacam bentuk kepemilikan, baik oleh swasta, negara, atau campuran.

Penerapan multitype ownership pada produk pembiayaan mudharabah dan musyarakah di bank syariah yaitu bahwa nasabah pembiayaan mudharabah dan musyarakah di bank syariah tidak terbatas pada nasabah individu tetapi juga bisa sebuah lembaga/ organisasi yang bisa mengajukan pembiayaan mudharabah di bank syariah. Begitupun dengan bentuk dana nasabah DPK mudharabah juga bisa berasal pada perseorangan, kelompok (badan hukum), dan atau untuk membiayai proyek-proyek yang dimiliki oleh pemerintah atau Negara.

\section{Freedom to Act (Kebebasan Bertindak dan Berusaha) \\ Freedom to act atau kebebasan} bertindak dan berusaha bagi setiap muslim. Islam memberikan kebebasan kepada setiap muslim dalam hal Muamalah, namun kebebasan tersebut memiliki batasanbatasan yang tidak boleh dilanggar.

Penerapan freedom to act (kebebasan bertindak dan berusaha) pada produk pembiayaan mudharabah dan musyarakah di bank syariah yaitu terlihat pada alokasi penyaluran dana, bank syariah bebas menyalurkan dana tersebut tanpa dibatasi jenis usahanya dan waktunya, selama usaha tersebut tidak melanggar aturan agama islam. Bank syariah diberi kebebasan untuk membiayai sebanyak mungkin usaha agar bisa memberikan keuntungan yang banyak, dan pastinya dengan analisis pembiayaan yang tepat. Kemudian bank dan nasabah mudharib bebas menentukan porsi/ nisbah bagi hasil beserta jangka waktu transaksi kegiatan mudharabah. Selama tidak ada pihak yang dirugikan. Nasabah mudharib bebas melakukan jenis usaha dalam mengelolah dana selama itu halal dan menguntungkan.

\section{Social Justice (Keadilan Sosial)}

Prinsip Social Justice lahir dari gabungan nilai khalifah dan nilai ma'ad. Semua sistem ekonomi yang ada pasti memiliki tujuan yang sama yaitu untuk menciptakan sistem perekonomian yang adil. Keadilan dalam pendistribuasian kekayaan adalah bagian dari prinsip ekonomi Islam. Islam melarang umatnya untuk menumpuk kekayaan pada satu kelompok, namun kekayaan haruslah didistribusikan secara merata. Kewajiban Zakat, Infak, dan shadaqah bagi golongan yang mampu adalah bentuk pendistribusian kekayaan dalam 
ekonomi Islam.

Penerapan social justice (keadilan sosial) pada produk pembiayaan mudharabah dan musyarakah di bank syariah yaitu bahwa penggunaan akad mudharabah di bank syariah menjadi cara dalam hal pendistribusian kekayaan. Melalui mekanisme mudharabah nasabah yang memiliki kelebihan dana, menyalurkan dananya untuk yang membutuhkan untuk pengembangan usaha, dengan menggunakan sistem bagi hasil. Kemudian setiap keuntungan yang diperoleh dari hasil usaha pembiayaan mudharabah jika telah mencapai nisabnya maka akan dikeluarkan zakatnya dan diberikan kepada kaum dhuafa. Atau jika nasabah mendapatkan finalty atau denda maka denda itu akan masuk sebagai dana sosial bukan sebagai pendapatan bank syariah yang juga akan disalurkan untuk sosial. Berbeda dengan bank konvensional yang menjadikan setiap denda yang ada adalah sebagai pendapatan bank.

\section{Akhlak}

Di atas semua nilai dan prinsip tersebut, dibangunlah konsep yang memayungi semuanya, yaitu konsep Akhlak. Akhlak menempati posisi puncak, karena inilah yang menjadi tujuan Islam dan dakwah para Nabi. Akhlak inilah yang menjadi panduan para pelaku ekonomi dan bisnis dalam melakukan aktivitasnya.

Penerapan akhlak pada produk pembiayaan mudharabah dan musyarakah di bank syariah yakni setiap usaha yang mendapat pembiayaan dari mudharabah dan musyarakah dipastikan halal dan tidak melanggar aturan agama, termasuk tidak boleh merusak moral manusia. Kemudian akhlak nampak pada nasabah debitur yang harus rajin dan jujur dalam melaporkan keuangannya dan pendapatan yang diperolehnya. Kedua belah pihak saling menjunjung saling percaya serta tidak saling mendzalimi satu sama lain, penuh dengan kejujuran dan ketaatan kepada aturan is- lam.

\section{Penutup}

$$
\text { Perkembangan pembiayaan }
$$

dengan akad Natural Uncertanty Contract (NUC) belum menjadi dominan dalam pembiayaan di bank syariah. Nampak pertumbuhan akad musyarakah berkembang sebesar 23,060 persen, hanya saja pembiayaan dengan akad mudharabah hanya sebesar 2,387 \% lebih kecil jika dibandingkan pembiayaan murabahah tumbuh sebesar 4,038 persen. Namun demikian secara nominal akad pembiayaan NCC lebih besar dibanding dengan pembiayaan dengan akad NUC.

Pada produk pembiayaan Natural Uncertainty Contract (NUC) di bank syariah yang terdiri dari mudharabah dan musyarakah telah banyak sejalan dengan konsep bangunan ekonomi islam. Sebagian besar dari konsep bangunan ekonomi islam diterapkan pada produk pembiayaan di bank syariah. Seperti diterapkan pada konsep Tauhid, nubuwwah, khilafah, ma'ad, kepemilikan multi jenis, kebebasan berbuat/ bertindak, dan keadilan sosial. Pada aspek adl' (keadilan) Nampak hal yang belum sesuai yaitu ketika nasabah/ mudharib dibebankan jaminan oleh bank syariah. Tidak semua mudharib memiliki barang yang bisa dijaminkan untuk mengajukan pembiayaan. Sebagaimana diketahui bahwa dananya akan digunakan untuk membiayai suatu usaha, akan tetapi usaha tersebut mengalami kerugian yang seharusnya nasabah dan bank syariah siap menanggung risiko kerugian. Akan tidak adil jika jaminan itu dicairkan oleh bank syariah jika usaha mudharib mengalami kerugian tanpa sengaja. Hal ini tidak sejalan dengan konsep adl' (keadilan).

\section{Daftar Pustaka}

\section{Al-Qur'an}

Abdul, Al-Mishri Sami'. 2006. Pilar-Pilar Ekonomi Islam. Pustaka Pelajar. Yo- 
gyakarta.

Alfiya, Evi. dan Muhammad Heykal. 2014. Analisa Pengendalian Internal Terhadap Pembiayaan Mudharabah Studi Kasus Pembiayaan Mudharabah Bank Syariah Mandiri Cabang Kebon Jeruk. Jurnal Binus Business Review 5(1). Universitas Bina Nusantara. Jakarta.

Algaoud Latifa M. dan Mervyn K. Lewis. 2001. Perbankan Syariah, Prinsip, Praktik, Prospek. PT. Serambi IImu Semesta. Jakarta.

Alwi, Syafaruddin. 2013. Memahami Sistem Perbankan Syariah Berkaca Pada Pasar Umar Bin Khattab. Buku Republika. Jakarta.

Apipudin. 2015. Kerjasama Pada Sistem Ekonomi Syariah (Analisis Atas Pembiayaan Akad Mudharabah). Jurnal IImiah Ekonomi Bisnis 20(1). Lembaga Penelitian Universitas Gunadarma. Jakarta.

Antonio, Muhammad Syafii. 2000. Bank Islam: Teori dan Praktek. Gema Insani Press. Jakarta.

Bin, Abdullah Muhammad Ath- Thayyar. etc. 2009. Ensiklopedi Fiqih Muamalah Dalam Pandangan 4 Madzhab. Maktabah Al- Hanif. Yogyakarta.

Chapra, M. Umar. 2001. Masa Depan IImu Ekonomi Sebuah Tinjauan Islam. Gema Insani Press. Jakarta.

Farizal. 2010. Pengembangan Kompetensi SDM Perbankan Syari'ah Melalui Corporate University. Forum Riset Perbankan Syariah II, Yogyakarta. Universitas Muhammadiyah Yogyakarta.

Hakiem, Hilman. dan Desi Sulfiaratih Waluyo. 2011. Musyarakah, Mudharabah dan Pertumbuhan Sektor Riil. Jurnal Ekonomi Islam AL-Infaq 2(1). Program Studi Ekonomi Islam Fakultas IImu Agama Islam Universitas
Ibnu Khaldun. Bogor.

Iska, Syukri. 2012. Sistem Perbankan Syariah di Indonesia dalam Perspektif Fikih Ekonomi. Fajar Media Press. Yogyakarta.

Isriani Hardini. dan Muh. H. Giharto. 2007. Kamus Perbankan Syariah Dilengkapi Penjelasan Singkat dan Perbandingan dengan Bank Konvensional. Marja. Bandung.

Inti, Russely Dwi Permata. etc. 2014. Analisis Pengaruh Pembiayaan Mudharabah dan Musyarakah Terhadap Tingkat Profitabilitas (Return On Equity) Studi Pada Bank Umum Syariah Yang Terdaftar di Bank Indonesia Periode Tahun 2009-2012. Jurnal Administrasi Bisnis (JAB) 12(1).

Karim, Adiwarman. 2006. Ekonomi Mikro Islam Edisi 3. PT Raja Grafindo Persada. Jakarta.

Muhamad. 2013. Manajemen Keuangan Syariah Analisis Fiqih dan Keuangan. Yogyakarta.

Munrokhim, Misanam. etc. 2008. Ekonomi Islam. PT. Raja Grafindo Persada. Jakarta.

Otoritas Jasa Keuangan. 2016. Statistik Perbankan Syari'ah.

Qardhawi, Yusuf. 1997. Norma dan Etika Ekonomi Islam. Penerbit Gema Insani Press. Yogyakarta.

Remy, Sutan Sjahdeini. 2014. Perbankan Syariah Produk-produk dan Aspekaspek Hukumnya. Kencana. Jakarta.

Sudarsono, Heri. 2005. Bank \& Lembaga Keuangan Syariah Deskripsi dan Ilustrasi Edisi 3. EKONISIA. Yogyakarta.

Triono, Dwi Condro. 2012. Ekonomi Mazhab Hamfara. Irtikaz. Yogyakarta.

Undang-undang No. 21 tahun 2008 tentang Perbankan Syariah http:// 
Trimulato. MediaTrend 12 (1) 2017 p.45-62

www.bi.go.id/web/id/Perbankan/

Perbankan+Syariah/. Diakses tanggal

14 Juni 2012.14 Juni 2012. 